\title{
Dilemas da Transição em Miguel de Unamuno e José Enrique Rodó
}

\author{
Elisângela da Silva Santos \\ Doutora em Ciências Sociais pela Universidade Estadual Paulista (Unesp-Marília) e Professora Adjunta da \\ Universidade Federal de Goiás (UFG). Jataí, GO, Brasil. \\ E-mail: licass20@yahoo.com.br, https:/ /orcid.org/0000-0003-2401-9999
}

El despertar del siglo fue en la historia de las ideas una aurora, y su ocaso en el tiempo es, también, un ocaso en la realidad.

(Rodó)

Atraviesa la sociedad española honda crisis: hay en su seno reajustes intimos, vivaz trasiego de elementos, hervor de descomposiciones y recombinaciones, y por

de fuera un desesperante marasmo.

(Unamuno)

\section{INTRODUÇÃO}

Tosé Enrique Rodó (1871-1917) e Miguel de Unamuno (1864-1936) realizaram importantes reflexões e exames acerca dos diversos dilemas enfrentados pela América Hispânica e pela Espanha no final do século XIX e no início do século XX. Em uma tentativa de traduzir os fenômenos de mudanças ou permanências em um momento crucial para as antigas colônias e a antiga metrópole, ofereceram explicações para além dos fatos circunstanciais e reuniram os anseios e incertezas de uma geração de intelectuais marcada pela dúvida do que superar de um século e do que levar para o outro. Em meio a um momento de bifurcação, especialização e dinamismo científico, suas angústias e medos estavam permeados pelo reconhecimento de suas tradições e heranças, e por uma ideia de retomada da unidade que marcava historicamente as duas regiões em questão. Se, no final do século XIX, a Espanha era decadente e necessitava regenerar, a América rejuvenescia e prometia, mas é necessário apontar que, nesse DADOS, Rio de Janeiro, vol.62(2):e20160045, 2019. 
momento, os autores vivenciavam o questionamento da hegemonia europeia, representada pelo antigo império espanhol.

Para Quijano (2005), o que hoje se considera América Latina ${ }^{1}$ se constituiu no atual padrão de poder mundialmente dominante e como parte desse padrão. Nesse espaço, estabeleceu-se o que o autor denominou de colonialidade e globalidade como fundamentos e modos constitutivos do novo padrão de poder surgido no século XVI. Isso significa dizer que o processo histórico que definiu a dependência histórica estrutural da América Latina e ofereceu espaço, no mesmo movimento, para a constituição da Europa Ocidental como centro mundial de controle desse poder partiu daí. Nesse movimento, também foram definidos os novos elementos materiais e subjetivos que fundaram o modo de existência social que recebeu o nome de modernidade.

Assim, os fundamentos da modernidade/colonialidade se localizam no descobrimento e na invenção da América, que foi a primeira entidade/identidade histórica do atual sistema colonial/moderno e de todo o período da modernidade. Entretanto, destaca o sociólogo peruano, da sede originária desse acontecimento histórico, da fonte original dos elementos básicos da nova sociedade mundial foram desposados seu lugar central, os atributos e os frutos de modernidade:

\begin{abstract}
Desse modo, nem todas as novas potencialidades históricas alcançaram seu pleno desenvolvimento na América Latina, nem o período histórico, nem a nova existência social no mundo chegaram a ser plenamente modernos. Ambos, enfim, se definiram e se reproduzem hoje como colonial/modernos (Quijano, 2005:10).
\end{abstract}

Eis o sentido básico das utopias produzidas na Europa, sendo que essas utopias podem ser reconhecidas na América Latina como o primeiro momento do processo de constituição de nossa modernidade, que assumia como conotação a luta por uma sociedade racional. A identificação dos povos de acordo com suas faltas e excessos é uma marca fundamental da diferença colonial.

Conforme destacou A. Morales (1992), os homens do século XIX, que viram cair o Antigo Regime, tiveram consciência de pertencer à era moderna, sentiram seu século como o século da crítica, no sentido amplo, da contínua discussão de valores e de problematização do 
presente. Na percepção de muitos, a América Latina estava vinculada à Europa de modo bastante "frouxo" e "inseguro" por meio de nossas antigas metrópoles - Espanha e Portugal -, cujo desenvolvimento técnico, social e intelectual se mostrava desarmado diante dos signos da modernidade. No entanto, diversos intelectuais da Ibero-América apostaram na integração, criando uma atmosfera otimista e encarando o colonizador como nosso elo com a civilização: "[...] o passado, como sede de uma idade para sempre perdida, foi substituído pelo futuro, como a idade dourada a ser conquistada ou por construir" (Quijano, 2007:12).

A crise de fim de século ${ }^{2}$ que atingiu a América e a Espanha apresentou como tarefa principal a ser enfrentada a definição de uma identidade cultural própria, problema debatido desde o processo de emancipação iniciado na primeira metade do século XIX. Esse período gerou uma gama de movimentos literários, artísticos e filosóficos tanto nas Américas quanto na Espanha - os modernismos literário e filosófico, o positivismo, o krausismo, o regeneracionismo, o idealismo, entre outros. Foi essa multiplicidade ideológica que atingiu, de forma distinta, diversos países do continente, o que dificulta a definição das filiações filosóficas dos autores aqui analisados, portanto não nos importa fixar Rodó e Unamuno em uma escola única de pensamento, mesmo porque suas obras não o permitem, em virtude de seu caráter híbrido. O que queremos ressaltar é que, em alguns momentos, está clara a filiação a determinado projeto filosófico e, em contrapartida, em outros não. Assim, comparar os pensamentos desses autores implica assinalar que existem semelhanças e diferenças entre situações sociais, países e biografias marcadas por condições sociais diversas que influenciaram suas experiências intelectuais.

Em Constelaciones Unamunianas: Enlaces entre España y América (18981920), Maíz (2009) afirma que os letrados desse ciclo definiram, de forma consciente, algumas estratégias de criação de espaços de pertença comuns e internacionalizados. Sua hipótese é que se constitui, entre 1898 e 1920, uma comunidade imaginada para além das fronteiras nacionais da Hispano-América e mais além dos obstáculos geográficos que o Oceano Atlântico representa. A língua e a palavra seriam os elementos de união e de entendimento dessa comunidade. Nesse sentido, há uma confluência entre os novecentistas hispano-americanos e os noventayochistas espanhóis, e Unamuno ocupa o centro de uma constelação discursiva. Seu aparato conceitual se ocupa 
de forma tão obsessiva do sujeito que tem como finalidade orientar o próprio discurso a outras vozes. Do mesmo modo, Rodó escreveu e atuou conforme a vontade de se converter em um guia intelectual de seu tempo. Como será possível observar, seus temas, seu estilo e sua concepção de literatura obedecem a essa ambição.

Assim, as proximidades temáticas entre as obras de Rodó e Unamuno são abordadas considerando os seguintes aspectos: na seção "Relações intelectuais: o resgate do passado", debate-se que tanto Rodó quanto Unamuno participaram de gerações que atuaram em prol da construção e da reconstrução de projetos para seus países. É sintetizada uma espécie de projeto coletivo idealizado e tematizado pelos autores, que lidavam com diferentes enredos sobre a modernização. Em "A pátria intelectual comum", realiza-se uma discussão sobre a possível unidade castelhana, que compreendeu o esforço de intelectuais hispano-americanos e espanhóis, e, além disso, a perspectiva de que a influência do cosmopolitismo importado da França estava prejudicando enormemente as repúblicas hispano-americanas no processo de difusão e de formulação de suas culturas originais. Em "O modernismo entre a fé e a razão", objetiva-se compreender como os diferentes modernismos - o religioso e o artístico - se comunicavam. É nesse momento que se percebe que a crise de fim de século originou também uma crise espiritual e religiosa em ambos os pensadores, pois estavam buscando novas razões para prosseguir em um mundo que perdia aos poucos seus sustentáculos divinos e mágicos, e também aos poucos desenhava sua marca: ausência de solidariedade social, fragmentação e instabilidade. Em "O equilíbrio entre Deus e ciência", percebe-se como a corrente positivista de pensamento, mesclada a outras, atingiu os pensamentos desses autores, que foram capazes de constituir interpretações interessantes, fomentando o debate sobre a importância adquirida pela ciência em detrimento das explicações místicas. Em "A heterodoxia religiosa", nota-se uma preocupação acentuada dos autores em debater e atualizar as formas religiosas, visando assim a uma espécie de conservação dessa esfera na temporalidade moderna. Se a modernidade "esmagava" as tradições, como as formas da tradição religiosa sobreviveriam nessa modernidade? Ou seja, conforme será visto, aí está presente uma espécie de apego a um espiritualismo visto por ambos como indispensável mesmo em um contexto em que as forças materiais pareciam dominar o pensar e o agir dos indivíduos. 


\section{RELAÇÕES INTELECTUAIS: O RESGATE DO PASSADO}

Entre 1900 e 1907, José Enrique Rodó e Miguel de Unamuno se comunicaram por meio de correspondências periódicas, em que discutiam suas produções e o momento histórico vivenciado por suas nações. Conforme a concepção rodoniana, a América Latina era proveniente da Espanha, e esse seria o principal elo histórico que necessitava ser resgatado e cultivado pela intelectualidade do momento. No começo do século $X X$, percebe-se que uma de suas maiores atuações como crítico literário e pensador foi a procura por raízes que conectassem os países do chamado Novo Mundo ao Velho Mundo. Uma das formas utilizadas por ele para manter contato com o mundo hispânico foi a troca de correspondências que estabeleceu com os principais escritores da América e da Espanha ${ }^{3}$.

A harmonia das ideias expressas nas cartas é resultado de um intenso debate travado por Rodó em seus livros: a integração continental tendo como traço comum a Espanha. Seu programa essencial reivindicava o dever de prosseguir a "luta intelectual" iniciada pelos "homens do passado", cujo principal objetivo era a formação da cultura latino-americana. Para Rodó, o problema fundamental da literatura produzida após a emancipação política era visto como uma questão crucial a ser enfrentada, pois a tendência dos "novos rumos" era cada vez mais o distanciamento da "pátria-mãe". Rodó alude à necessidade de permanência dos traços espanhóis na cultura hispano-americana como algo indispensável para o desenvolvimento cultural da ex-colônia.

O primeiro grande desafio de Rodó quando iniciou a carreira como escritor profissional ainda muito jovem, aos 24 anos, foi a criação, em 1895, com outros autores, de La Revista Nacional de Literatura y Ciencias Sociales, com sede em Montevidéu. A revista durou dois anos e foi o primeiro periódico sobre literatura e sociedade do Uruguai. Teve a participação de Rodó, Víctor Pérez Petit (1871-1947) e os irmãos Carlos Martínez Vigil (1870-1949) e Daniel Martínez Vigil (1867-1940). Em suas páginas, reuniu, durante o primeiro ano de existência, a mais representativa intelectualidade uruguaia. No segundo ano, estabeleceu relações com os centros mais cultos do continente: Santiago do Chile, Buenos Aires, Lima, Caracas, Colômbia, Equador e até com a Espanha. 
A chamada Generación de Novecentos, da qual Rodó fez parte, foi uma geração de autodidatas. Por isso, por mais que as leituras fossem compartilhadas, não resultavam em uma compreensão uniforme do momento. Nesse sentido, não se pode falar de uma ideologia dos Novecentos, mas sim de um ambiente intelectual caracterizado pela discussão sobre a cultura e a sociedade. Exaltavam-se o poder criador do indivíduo e a capacidade de modificar a história, a subjetividade e os valores espirituais. Os nomes ${ }^{4}$ que fizeram parte dessa geração de intelectuais concebiam a literatura por meio do plano universal e tinham como objetivo incorporar a literatura uruguaia à grande tradição literária ocidental. Esse era o fim de século uruguaio, em um país em processo de modernização, recebendo os influxos da imigração, deixando o perfil rural, sofrendo da condição colonial e tentando legitimar uma intelectualidade preocupada com a formação da nação.

Foi nesse momento que a Espanha também se voltou para a Hispano-América a fim de reconquistar suas ex-colônias, mas sem a mesma base exploradora da primeira colonização. Isso pode ser explicado em razão do distanciamento entre a Europa e a Espanha. Segundo Cúneo (1997), enquanto o restante do continente se modernizava de forma espantosa, a Espanha empobrecia, problema agravado pela perda de suas últimas colônias e também pela corrupção política e pela mentalidade arcaica dos grandes proprietários rurais, que não incentivavam o desenvolvimento da industrialização. Sendo assim, a Europa se mostrava burguesa em sua plenitude, e a Espanha um país relegado, solitário e empobrecido, que necessitava se regenerar.

Unamuno se esforçava nesse momento para realizar uma reaproximação entre a Hispano-América e a Espanha. Dizia que esta estaria mais perto do chamado Novo Mundo do que do Velho; a "mãe" não conhecia suas "filhas" e vice-versa, o que ocasionava uma situação de incompreensão e preconceito. Unamuno utilizava o termo hispanidad, e não españolidad, pois acreditava que assim estava incluindo todas as linhagens e raças espirituais hispânicas. Segundo Chaves (1964:31),

Unamuno proclama a fraternidade entre os povos hispânicos, que será alcançada por meio da igualdade. Igualdade entre Espanha e América; igualdade entre todas as nações hispanofalantes. Para isso, é necessário 
que todos trabalhem em um mesmo projeto, com idêntica personalidade e igualdade de direitos.

Ao lado de outros nomes ${ }^{5}$, Unamuno integra a chamada Generación de 1898. Encarados como os regeneracionistas, são autores que vivenciaram o estado decadente em que a Espanha se encontrava, conforme já apontado, coroado pela perda de suas últimas colônias - Cuba, Porto Rico e Filipinas - para os Estados Unidos da América em 1898. Os autores dessa geração buscavam analisar as causas "desse mal" e propunham soluções para regenerar o país. Realizaram uma crítica profunda sobre a Espanha e tentaram solidificar teorias otimistas para a reconstrução do futuro do país. O futuro implicava uma modernização das ideias e da sociedade, e essa seria a única forma de retirar a Espanha de seu isolamento ${ }^{6}$.

Um dos grandes objetivos dessa geração era realizar uma análise interna da Espanha, saber de sua história, de sua natureza, da gente e de seus costumes. A Espanha e o cidadão espanhol constituiriam os temas centrais e predominantes. Além disso, os autores realizariam o debate sobre a abertura da Espanha para o restante do continente europeu.

O que podemos perceber na intelligentsia uruguaia e na espanhola é um grande ensejo de construção e reconstrução de ideias para seus respectivos países. A Geração dos Novecentos, marcada pela heterogeneidade, imprime uma ideia de modernismo literário em um momento de abertura do positivismo a novas tendências filosóficas. Já a Geração de 1898 representa um momento conjuntural no mundo hispânico, oferecendo margem a uma espécie de integração entre a Espanha e suas antigas colônias. Para tanto, a antiga metrópole deveria desposar-se de suas pretensões como potência imperial e enfrentar a realidade de simples nação entre outras.

É interessante apontar o peso da cultura espanhola desse momento na configuração do ideário rodoniano. Os reflexos dos desafios espanhóis rumo à modernização são sentidos nas antigas colônias. O resultado dessa reaproximação resulta em uma "inversão histórica", uma vez que os países se reencontram, e a Espanha tenta conter a influência dos Estados Unidos sobre os países ibero-americanos. 


\section{A PÁTRIA INTELECTUAL COMUM}

Todo propósito de autonomía literaria que no empiece por reconocer la necesidad de la vinculación fundamental de nuestro espíritu

con el de los pueblos a quienes pertenece el derecho de la iniciativa y de la dirección, por la fuerza y la originalidad del pensamiento, será, además de inútil, estrecho y engañoso.

(Rodó)

España es depositaria del patrimonio espiritual de una gran raza.

(Unamuno)

Apesar de muitos autores espanhóis da Geração de 1898 terem projetado uma reaproximação entre a Espanha e suas "antigas filhas", proclamando uma "igualdade" entre as nações em virtude de suas origens históricas entrelaçadas, é possível problematizar essa relação "amistosa" por meio do questionamento trazido por Díaz-Quinõnes (1998:131): "Era ou é possível se pensar como membro de uma comunidade 'hispano-americana' que tenha a Espanha como centro, como se ambos os mundos fossem apenas um e o mesmo?".

Dessa forma, o que podemos observar é uma recolocação da literatura hispano-americana após a independência política das nações, pois o grande desafio era fundar as próprias tradições culturais e, por mais que a França fosse o grande modelo estético da modernidade, a Espanha representava uma ruína que deveria ser reerguida.

A literatura hispano-americana e as reflexões a seu respeito também se nutriram do emergente discurso latino-americanista pós-1850. Segundo Ramos (2008), a América Latina existe como um campo de batalha em que diversos postulados e discursos têm lutado historicamente para impor e neutralizar suas representações da experiência continental.

Rodó apresentava uma perspectiva de fidelidade às "leis" de sua origem. Ressalta-se, por exemplo, sua tentativa em La Revista Nacional de Literatura y Ciencias Sociales de oferecer memória aos autores hispano- 
-americanos, desde os tempos das colônias até a literatura produzida por seus coetâneos. Constantemente apontava para a indivisibilidade de uma só e grande pátria literária.

Cortazzo (1986) aposta na ideia de elaboração de uma tradição literária empreendida por Rodó, e essa defesa da tradição é a defesa da continuidade em um mundo de mudanças frequentes. A revolução trouxe como consequência a fragmentação do antigo império em diversas repúblicas que pareciam se desconhecer:

No programa de unificação, a literatura desempenha um papel fundamental: consolidar e preparar o triunfo da utopia, desenvolvendo o sentimento 'americanista'. Em outras palavras, promovendo e assegurando a unidade essencial de todas as nações latino-americanas (Cortazzo, 1986:27).

No entanto, o grande problema enfrentado inicialmente era a ausência de clássicos na literatura do continente. Por isso, Rodó encontrou diversas dificuldades ao inaugurar sua atividade como crítico literário em 1895, como mencionado, aos 24 anos:

O intercâmbio de ideias e de inteligência; as correntes mensageiras da atividade da vida intelectual; o amor revelado na consideração das coisas de alguns pela mente seleta de outros são vínculos mais fortes, mais seguros que os que podem surgir da organização oficial e artificial das instituições que controlam, em cada área da vasta unidade castelhana, como vestais, a integridade ou a imobilidade da língua. (Rodó, 1957:809)

A "vasta unidade castelhana" aludida pelo autor também compreendia o esforço de intelectuais espanhóis daquele momento, como o próprio Miguel de Unamuno e o crítico Leopoldo Alas (1852-1901), de pseudônimo Clarín. Rodó atribui a este a qualidade de melhor e mais influente crítico espanhol do último quarto do século XIX, pois representa o anseio por novidades que surgem como presságios renovadores naquele momento.

Segundo A. Morales (1992), Clarín é uma influência central na obra de Rodó, pois, como crítico da atualidade, realizou uma discussão sobre a queda do Antigo Regime, sentindo seu século como o século da crítica no sentido mais amplo: na contínua discussão de valores e 
na problematização do presente. Clarín, ressalta A. Morales (1992), serviu-se do conceito de oportunidade para julgar os distintos movimentos literários do último terço do século XIX, entre eles o naturalismo, cuja introdução na Espanha, em 1880, provocou polêmica. Embora não tenha aceitado a doutrina de Zola em seus extremos, Clarín defendeu o naturalismo porque via nele a tendência mais oportuna daquele tempo. Como consequência de sua concepção de oportunidade, sustentou também o caráter relativo das formas literárias: cada época tem um gênero literário privilegiado por meio do qual se expressa plenamente.

A crise do naturalismo foi sentida pelos intelectuais da época como uma manifestação da crise da concepção positivista do mundo, como mais um sintoma do surgimento de uma nova tendência histórica geral, o que se chamou de um espírito novo e se caracterizou como reação, restauração ou renascimento idealista ou espiritualista. Para A. Morales,

Clarín foi um dos primeiros intelectuais espanhóis a ter consciência e a se identificar com essa mudança, com o surgimento de um espírito novo caracterizado pelo renascimento do idealismo na arte, na filosofia, na política e nas demais esferas da vida humana. No entanto, dizer que o espiritualismo dos últimos anos coincidia com a orientação geral da época não bastava: era também pessoal e matizado, respondia a um impulso interior mais profundo e mais complexo. (1992:6)

Rodó foi um grande leitor de Alas, e é muito provável, conforme A. Morales, que tivesse em conta o plano dos folhetos literários que Clarín vinha publicando desde 1886 . O espírito novo, caracterizado pelo idealismo e pela religiosidade, vinha contrastar com o positivismo estreito e o egoísmo generalizado do mundo moderno. Para Clarín, esse espírito havia se manifestado primeiramente na literatura. Acreditava que, no seio dessa juventude literária americana, surgiam sintomas para uma reação favorável, que voltava os olhos para a Espanha sem renegar o passado e sem desdenhar as úteis lições recebidas da comunicação direta com os países europeus mais adiantados. Na visão de Clarín, essa originalidade deveria ser buscada a todo custo e não poderia ser fruto de importações, mas sim ser sondada nos "mistérios da herança", no fundo da raça. 
Ao receber o livro Ariel, de Rodó, Clarín viu cumprir grande parte de suas esperanças. A ele parecia que as novas gerações hispano-americanas se encaminhavam para o novo idealismo. Acreditava que a obra fosse finalmente a expressão de uma ideologia totalizadora, a harmonização dos conflitos culturais, políticos e sociais que haviam surgido no século XIX. Tanto acreditou na obra de Rodó que a difundiu entre seus companheiros krausistas da Universidad de Oviedo, entre eles Rafael de Altamira (1866-1951), apresentando-a como exemplo para os novos escritores americanos e espanhóis. Na resenha enviada em uma das correspondências trocadas, posteriormente incorporada como prólogo a uma das edições de Ariel, Clarín teceu os seguintes elogios à obra mais conhecida de Rodó:

Agora publica o sr. Rodó um livro de poucas mas substanciosas páginas intitulado Ariel, e, embora não trate nele diretamente dessa nova tendência de reconciliação com a Espanha, a Espanha digna do século, ainda que respeitosa com os séculos de sua glória; embora Ariel tenha outro fim imediato, no fundo e como corolário de sua ideia é o mesmo. Ariel não é uma novela nem um livro didático; é um gênero intermediário que com tão bom êxito cultivam os franceses, e que na Espanha é quase desconhecido. (Alas, 1961:14)

Nesse estudo crítico, foram tecidos diversos elogios a Ariel, pois, para o crítico espanhol, são admiráveis a profundidade e a serena unção com que Rodó sabe atingir a harmonia, sempre inspirada pela justiça. Por isso, recomenda a leitura da obra aos literatos decadentes e modernistas, e também aos jovens autodeclarados ácratas e libertários o estudo desse espírito americano, tão jovem e equilibrado, sereno e imparcial, sem miséria de entusiasmo, apaixonado pelo futuro, mas com veneração pelo passado e com conhecimento positivo do presente. Apesar dos elogios de Clarín a Ariel, o crítico faz uma observação sobre a influência francesa, que tanto incomodava os espanhóis naquele momento. Já Unamuno discordava de Clarín por este considerar Rodó um exemplo de novo escritor. Em carta privada a Clarín, afirma que leu o conteúdo da obra em muitos autores franceses.

Observa-se que esse debate que se inicia desde a definição do nome América Latina e perpassa a afirmação de uma identidade ibero-americana, latino-americana e hispano-americana é resultado de um esforço declarado dos intelectuais considerados neste artigo. Entre os 
principais enigmas para os hispano-americanos, está a necessidade de redefinir a relação com a cultura ocidental. Para os espanhóis, a diluição da Espanha na cultura europeia seria ou não a solução para enfrentar sua crise?

No interior dessa "pátria intelectual" (termo cunhado por Rodó), ocorreria, como destacou Maíz (2009), um febril ativismo, incluindo instituições, academias, ateneus, salas de redação de periódico, revistas, encontros e até grêmios intelectuais. Para integrar essa pátria, são requeridos o cultivo da inteligência, o exercício das letras e uma mínima noção de solidariedade. A pátria intelectual pode ser pensada em contraposição à República Mundial das Letras, que tem sua capital em Paris. Nasce de uma necessidade de conter e de integrar os intelectuais periféricos, impedindo muitos deles de se influenciar pelas "pestes pegajosas de Paris" (expressão de Clarín). Segundo Maíz (2009:21),

o saldo mais evidente dessa comunicação entre a Espanha e a América foi
a formação da "pátria intelectual" imaginada, um lugar ideal em que os
homens letrados poderiam não apenas se conectar entre si mas também
elaborar pontos de vista, refinar ideias, projetar programas com o objetivo
de criar uma sociedade de homens reunidos pelo uso de um instrumento
comum: a língua.

O conhecimento de Unamuno sobre a América foi adquirido graças à leitura das obras de escritores hispano-americanos que ele recebia em grande quantidade. Desde as primeiras leituras, Unamuno questionava a busca de uma originalidade por meio do acento estrangeiro que os povos desse continente observavam por detrás da lente da França, o que os distanciava ainda mais da Espanha.

Em 1901, Unamuno iniciou suas crônicas sobre a literatura hispano-americana na revista La Lectura. Em texto de 1905 intitulado "Algunas consideraciones sobre la literatura hispanoamericana: a propósito de un libro peruano", Unamuno enxergava como necessária essa pátria intelectual, por isso contradizia a ideia de que a língua espanhola estivesse em vias de desaparecer da América. Refutava essa perspectiva não por "patriotería" - vício do qual se dizia livre por não acreditar que a Espanha seria a metrópole da cultura -, mas sim porque o castelhano se estendeu às terras 
dilatadas e apartadas, por isso teria de se converter em língua de todas elas:

A néscia e torpe política metropolitana nos fez perder as colônias, e uma não menos néscia nem torpe conduta em questão de língua e de literatura poderia nos fazer perder - se essas coisas se regessem por procedimentos de escritores e literatos - a irmandade espiritual. Temos que parar de perder, os espanhóis, tudo o que se inclui nisso de pátria mãe e compreender que, para salvar a cultura hispânica, é preciso começar a trabalhar em parceria com os povos americanos, e recebendo deles, não somente dando-lhes. (Unamuno, 1968a:97)

Para Unamuno, portanto, a literatura espanhola não se diferencia substancialmente nem na forma nem no conteúdo das literaturas hispano-americanas. Estas seriam uma continuação da Espanha do século XVI; e o que seria certo afirmar era que os escritores espanhóis haviam, sim, influenciado na América, e esse elo deveria ser ressaltado e fortalecido.

María Belén de Castro Morales (1990) destaca que muitos estudos já foram feitos sobre a importância da literatura francesa na formação do modernismo hispano-americano e que, por isso, haveria a necessidade também de buscar os efeitos da literatura espanhola nesse movimento modernista em um período em que o objetivo era o fortalecimento dessa orientação intelectual que soube assimilar e "reciclar" elementos de diversas procedências.

Para Unamuno, a literatura francesa teria causado muitos "estragos" à Espanha. Afirmou que nada mais falso, vão e desagradável que os escritores espanhóis formados na imitação da literatura francesa:

É uma literatura sensual e lógica, e, portanto, iluminada e alegre. E nós, os espanhóis, somos, em geral, mais apaixonados que sensuais e mais arbitrários que lógicos. Somos e devemos continuar sendo. Ou melhor, devemos voltar a sê-lo, porque talvez não o sejamos tanto, menos ainda como em outros tempos o fomos. (Unamuno, 1968a:129).

A discussão de Unamuno no final do século XIX e no início do século XX trazia como grande tarefa compreender como modernizar e europeizar a Espanha sem deixar de ser espanhol. Diz que seu país se 
empenhou sempre em deformar seu espírito conforme um padrão de fora, originando uma terrível mestiçagem espiritual e um hibridismo infecundo. Para Maíz (2009), Unamuno põe em crise o discurso da modernidade no interior de si mesma ao questionar as noções de tempo (o eternismo diante da ideia de progresso), a história (a que interpela com a noção de intra-história), a religiosidade (uma fé sem dogma) e o discurso literário. Tal singularidade está no fato de pensar esses problemas estando na periferia europeia e afirmando essa contradição como o atributo digno de um pensamento autônomo, embora não original.

Segundo Litvak (1990), foi por causa disso que Unamuno decidiu estudar a população rural espanhola, que, de acordo com sua rotina secular, revelaria a verdadeira essência hispânica. Unamuno dizia que a ideia de cosmopolitismo que tanto havia contagiado a América Latina e muitos espanhóis não era somente uma fuga da realidade e um refúgio em um mundo estranho, mas sim uma consequência da chamada arte livre, que, ao romper com as normas das sociedades ditas pré-modernas, aderiu àquilo que lhe parecia estranho.

Estamos diante de três perspectivas - Rodó, Unamuno e Clarín - que problematizaram a literatura produzida nesse momento na Hispano-América e na Espanha. Os três viram com muitas ressalvas o modernismo. Conforme apontou A. Morales (1992), a história da palavra "modernismo" é tão complexa quanto o período que acabou designando. Termos como "moderno" e "modernista" foram entendidos de diversas formas e ostentados por personalidades muito diferentes.

Clarín questionou esse movimento dizendo que se tratava de afrancesamento, desconhecimento da gramática e da tradição literária espanhola, gongorismo - estilo literário desenvolvido entre os séculos XVI e XVII, representado por Góngora e caracterizado pela riqueza de imagens e pelo uso de cultismos, sintaxe complicada e dirigido a uma minoria seleta -, colorismo, confusão entre as artes, desvarios e imoralidade. No caso de Rodó e de Unamuno, podemos ilustrar suas críticas ao modernismo por meio da figura de Rubén Darío (1867-1916).

Sobre essa inconsistência modernista, no artigo intitulado "Rubén Darío: su personalidad literaria, su última obra", de 1889, Rodó afirma que o poeta nicaraguense não poderia ser visto como o poeta da América, como denominava a crítica, pois estava separado do que 
ocorria ao seu redor. Rodó não pretendia dizer que Darío tinha uma condição de inferioridade literária, mas não poderia ser encarado como o representante máximo da americanidade continental, uma vez que não tínhamos, ainda, condições de eleger um autor como tal, pois a arte estava em processo de formação e apresentava um "solo pouco generoso" para definirmos esse poeta como o "guardião" da originalidade literária do continente.

Apesar de todas as críticas dirigidas à poesia de Darío, Rodó dizia não ser um adversário do poeta, pois compartilhavam o mesmo objetivo: o reconhecimento da cultura latino-americana. Rodó não negava seu modernismo, até porque, como bem apontou A. Morales (1992), poucos intelectuais do final do século XIX teriam dito abertamente que não eram modernistas: "Eu também sou um modernista, pertenço com toda a minha alma à grande reação que dá caráter e sentido à evolução do pensamento no final deste século" (Rodó, 1957:187).

Rodó se apresenta como a voz crítica, moderada e prudente que advertia os extremos perigosos desse modernismo que, em sua visão, não deveria ter interesse exclusivo pelo artístico e desinteresse pelos demais temas. Para isso, seu conteúdo deveria também se voltar para os dilemas do momento, uma vez que era pobre de ideias.

Assim como Rodó, Unamuno tinha algumas reservas em relação ao modernismo na poesia. Em carta a Rubén Darío datada de 1899, afirmou que não sentia nenhuma atração por Paris: "Sou refratário por um defeito meu, sem dúvida, às elegâncias refinadas de Paris..." (Unamuno apud López, 1984:46). A crítica de Unamuno ao poeta nicaraguense perpassava a ideia de que muitos atribuíam à poesia de Darío uma revolução no idioma espanhol, mas, na realidade, o que ocorria era justamente o contrário: observava o mundo de modo muito pouco castelhano: “Que o progresso seja o progresso de tradição é indispensável, e, para sê-lo, para revolucionar a língua, devem se aprofundar os valores. É necessário cavar até o subsolo para lavrá-la melhor" (Unamuno, 2002:23).

Para Unamuno (1968a), em vez de se ocuparem com temas castiços, mitológicos, os modernistas - sobretudo o poeta Rubén Darío - se refugiaram demasiadamente no espírito francês. Por isso, Unamuno via os modernistas como traduções francesas. Em sua opinião, o modernismo não passava de um ridículo esteticismo: 
Os estrangeiros, sobretudo os franceses, não apreendem de nós a não ser o menos nosso, o que menos abala seu espírito - e isso é natural -, o que se acomoda à ideia que eles têm de nós, ideia que é sempre e forçosamente superficial. E, nós, pobrezinhos, cedemos a esse falacioso agrado e esperamos o aplauso de fora, dos que, na realidade, não nos entendem e, ainda que nos entendam, não nos compreendem. (1968a:122)

O que se observa nesse trecho de Unamuno é uma crítica comum em sua obra: a Espanha se conhecia pouco e, ao mesmo tempo, conhecia mal a América, que também não conhecia a Espanha. Além disso, as próprias repúblicas hispano-americanas se conheciam superficialmente. Daí a proposta de Unamuno de constituir uma entidade autônoma formada pela unidade da língua e da literatura espanhola:

E assim a raça. Na América, vai se desenvolver a espanhola, a raça histórica, a que tem por sangue a língua, potencialidades que aqui se desgastam e se enfraquecem, atrofiadas pela falta de uso. E, lá, por sua vez, nossa fala vai se enriquecer e se tornar mais complexa, flexibilizando seus contornos rígidos. Em tão vasto e variados domínios, vai se cumprir uma diferenciação maior de nossa raça histórica, e a língua vai integrar as diferenças assim alcançadas. (2002:23)

Desse modo, conforme observou Maíz (2010), o que podemos assegurar é que Unamuno defendia uma harmonia da "raça hispânica" bastante fincada na história europeia, com a hispano-americana dando continuidade mediante o processo de descaracterização da identidade dos povos periféricos atingidos pela racionalidade científica e pelo estrangeirismo artístico e acadêmico.

O MODERNISMO ENTRE A FÉ E A RAZÃO

Lo religioso es un modo de hacer todo y de ser todo.

(Unamuno)

Pero crea usted que nada me inspira más respecto que la sinceridad religiosa. (Rodó) 
Rodó e Unamuno viveram a crise de fim de século como uma onda avassaladora. Diante dos "novos tempos", que apontavam no horizonte em velocidade jamais vista, lançaram mão de ideias conservadoras e propuseram a restauração de um poder espiritual que, em compasso com a nova sociedade, pudesse fornecer parâmetros e limites para o tempo da ciência e da indústria. Desse modo, o objetivo, neste item, é analisar as facetas do modernismo presentes nos debates de Rodó e de Unamuno. Como será visto, esse foi o momento em que os debates sobre as produções artísticas e sobre as correntes filosóficas e literárias se intensificaram e apontaram para a necessidade de atualizar suas formas, seguindo o ritmo impresso pela modernidade. Contudo, ambos os autores questionaram o lugar secundário atribuído às questões espirituais, ambos problematizaram os movimentos artísticos e intelectuais que compartimentaram as esferas da fé e da razão, e recusaram os aspectos considerados "artificiais" da modernização.

Os pensadores em questão denunciam uma nostalgia pela totalidade e pelo transcendente, estão ligados a uma visão que talvez pudéssemos dizer romântica. Löwy e Sayre (1993) definem que a visão romântica é, por essência, uma reação contra as condições de vida na sociedade capitalista; uma sociedade fundada sobre o dinheiro e sobre a concorrência que separa os indivíduos em nômades e egoístas, hostis e indiferentes aos outros:

A experiência da perda está ligada a essa revolta contra o capitalismo: no real moderno algo precioso se perdeu, tanto no que concerne ao indivíduo quanto à humanidade. A visão romântica caracteriza-se pela dolorosa convicção de que faltam ao real presente certos valores humanos essenciais que foram alienados. (Löwy e Sayre, 1993:22).

Entre os tipos de romantismo definidos pelos autores, está o romantismo "restitucionista", que visa restabelecer normas sociais e culturais pré-capitalistas desaparecidas, ou seja, aspira à restituição, à restauração ou à recriação do passado no presente. Esse aspecto está bastante ressaltado nas obras dos autores abordados aqui, porém, no momento em que escrevem, marcado pela onda avassaladora em busca do cientificismo, assumem uma conotação ambígua: ao mesmo tempo que não queriam abandonar a ordem anterior, deparam-se com a promessa de liberdade, igualdade, solidariedade e de melhora contínua das condições materiais que a temporalidade técnica oferecia. 
Mesmo assim, é importante ressaltar que todo o debate empreendido por Rodó e por Unamuno com relação à crise de fim de século foi constituído no âmbito do modernismo, seja no domínio literário, seja no filosófico, movimento que também fazia parte da discussão empreendida na Espanha e na Hispano-América. Esse aspecto foi denominado por Rama (1985) como parte de certo "isocronismo", pois transformações literárias do Novo Mundo seguiam muito próximas daquelas produzidas nos centros culturais do mundo.

O isocronismo cultural vivenciado no final do século XIX teve consequências imediatas sobre os escritores, que se viam incentivados a buscar, de uma vez só, uma multiplicidade de caminhos, estilos, temas e um amplo setor de diferenças que, ainda conforme Rama, se assenta em uma tentativa de consolidação de uma literatura orgânica: "[...] a tarefa histórica que estava destinada a intensificar a vinculação com o passado nacional para gerar a ideia de nação em uma massa recém-descolonizada (1985:45).

Esse debate feito por Rama (1985) é de profundo interesse neste artigo, uma vez que, ao se resgatar a discussão sobre a modernidade nas obras de Rodó e de Unamuno, se percebe que ambos fazem parte do mesmo contexto e que os grandes temas tratados por eles se encontram, o que reafirma a hipótese da isocronia. Segundo Aguinaga (1984), o período que antecede 1898 foi marcado pela união de autores espanhóis e americanos, e os aspectos que proporcionaram essa situação foram: a idade, a língua, o assalto à retórica anterior, certas ideias tradicionais e o reconhecimento mútuo por meio de suas publicações.

A discussão desencadeada com o modernismo e o "regeneracionismo espanhol", desenvolvidos entre 1890-1910, envolveu a teologia e a ciência, a Igreja e o mundo. Unamuno era um dos autores que apontavam que o modernismo literário poderia ser confundido com o modernismo religioso. Segundo Martínez:

Modernismo religioso e modernismo literário são conceitos que repousam em um adjetivo (moderno) cujo significado pode ser aplicado a qualquer realidade em mudança em relação a um passado que começa a se ver como obsoleto e que, por isso, pode referir-se a realidades distintas ou análogas e não obrigatoriamente simultâneas. (2009:102). 
É interessante apontar que, enquanto a Europa ibérica discutia o tema do modernismo literário atrelado ao religioso, conforme Berman (1986), grande parte do restante do continente apostava em uma experiência ambiental da modernidade anuladora das fronteiras geográficas e raciais, de classe e nacionalidade, de religião e ideologia, que pressupunha uma unidade de vida e de experiência. Os ritmos e os timbres peculiares da modernidade - a rigor, europeia - advêm da nova paisagem desenvolvida, diferenciada e dinâmica. A moderna humanidade se vê em meio a uma enorme ausência de vazios, mas, ao mesmo tempo, em meio a uma desconcertante abundância de possibilidades.

No caso espanhol, a obra de Unamuno denuncia como se dava a articulação da Espanha com os debates europeus. Segundo ele, a adesão ao pensamento racional e filosófico iluminista na Espanha se estabelecia de acordo com as raízes religiosas, e não pelo humanismo secular que se espalhava pela Europa:

Por que se propagou aqui, na Espanha, o krausismo, e não o hegelianismo ou o kantismo, sendo estes sistemas muito mais profundos, racional e filosoficamente, do que aquele? Porque aquele nos foi trazido com raízes. O pensamento filosófico de um povo ou de uma época é como sua flor, é aquilo que está fora e está em cima; mas essa flor, ou, caso se queira, fruto, toma seus sumos das raízes da planta, e as raízes, que estão dentro e estão embaixo da terra, são o sentimento religioso. Se Ríanse deixou aqui algumas raízes - mais do que se acredita e não tão efêmeras quanto se supõe -, foi porque Krause tinha raízes pietistas, e o pietismo, conforme demonstrou Ritschl em Geschichte der Pietismus [História do pietismo], tem raízes especificamente católicas e significa, em grande medida, a invasão, ou melhor, a persistência do misticismo católico no seio do racionalismo protestante. Assim se explica que se krausisaram aqui até muitos pensadores católicos. (Unamuno apud Casanova, 1993:108).

De acordo com María Stier (2009), romantismo, positivismo e krausismo, entre outras correntes, ao serem incorporados no mundo hispânico, tiveram como traço o humanismo e o cristianismo. Ainda conforme a autora, foi no mesmo período em que o positivismo influencia a Península Ibérica e suas antigas colônias que o krausismo, filosofia de natureza espiritualista que fazia parte do idealismo alemão, também chega ao continente latino-americano. Tratava-se de 
uma derivação da filosofia de Karl Christian Friedrich Krause, que pretendia ser o único e autêntico herdeiro de Kant:

Enquanto o krausismo não teve nenhuma importância na Alemanha, na Espanha, por meio de Julián Sanz del Río, converteu-se no movimento mais importante contra o tradicionalismo, o neoclassicismo e toda tendência conservadora. Converteu-se em uma espécie de religião laica, em uma nova visão do homem como síntese do universo. (Stier, 2009:59).

Para Unamuno, o espiritualismo místico fazia parte da essência espanhola, e a adesão a esse pensamento místico também poderia ser justificada em virtude da cultura católica espanhola; por isso, segundo sua concepção, para apreender o caráter do país, a análise deveria passar pela esfera religiosa:

Os povos hispano-americanos, o mesmo que na Espanha, e em geral os que chamamos de povos latinos, devendo ser chamados de católicos, não saem da Igreja senão para cair no que se chama de livre pensamento e que é uma atitude intelectualista que repousa inerte no fundo religioso. Educados no intelectualismo católico, em dogmas, em construções conceituais, em supostas provas lógicas da existência de Deus, em uma fé parcial, quando a cultura científica e filosófica lhes aparta dela, não sabem chegar à fé viva, à fé independente de dogmas. Mesmo sendo ateus, seguem no fundo sendo católicos, quer dizer, intelectualistas e dogmáticos. É daí que o anticatolicismo acaba nos países de tradição católica por ser anticristianismo e antirreligiosidade. (Unamuno, 1968a:86).

Considerando as reflexões sobre a questão religiosa de José Enrique Rodó, percebe-se que o tema aparece em sua obra de forma fragmentária e descontínua, e a recepção do modernismo religioso na Espanha contribuiu para o intercâmbio de reflexões desses pensadores sobre o pensamento religioso.

Conforme a ponderação rodoniana, um dos traços mais importantes do pensamento hispano-americano é a "vigorosa" manifestação do sentido idealista da vida. Frequentemente os autores escrevem e pensam com a finalidade espiritualista.

O pensador uruguaio enaltece aquilo que concebe por tolerância (ou direito ao foro íntimo) religiosa em um contexto em que a Ciência 
e a Razão, bem como a Política, se tornavam os principais assuntos da intelectualidade naquele momento. Rodó realizou uma crítica à adesão às campanhas anticlericais europeias que atingiam de modo substancial a América Latina. Para Rodó, ao jovem continente não caberiam as mesmas reivindicações europeias. Dizia abominar essa mescla de sentimentos que aqui, segundo ele, era forçosa: "[...] só quero negar a oportunidade do debate religioso nos estreitos limites da vida política" (Rodó, 1957:506).

Dessa forma, percebe-se que o terreno social em que Rodó atuava naquele momento se debatia entre estabelecer um sistema educacional para a sociedade uruguaia, sobretudo para educar sua juventude, sem a ruptura com seus elementos culturais tradicionais. Em 1898, Rodó foi designado interinamente catedrático de literatura na Universidad de la República, função a que renunciou em 1902. Tentava contribuir para que a transição do pensamento religioso para um pensamento político e filosófico seculares ocorresse sem traumas e sem mudanças bruscas capazes de desequilibrar a ordem até então seguida. Rodó afirma que o movimento das ideias tendia cada vez mais para o individualismo, a dispersão de vontades e de forças, e uma variedade inarmônica, signo da transição.

Em 1896, em um de seus primeiros textos publicados em La Revista Nacional de Literatura y Ciencias Sociales - "El que vendrá" -, Rodó realiza uma espécie de "balanço" sobre as inquietações do final do século, denunciando a preocupação com os tempos modernistas vindouros. Os questionamentos sobre os presságios e as incertezas são inúmeros e denotam uma busca de rumos e de rotas a seguir. Em tom de súplica, relata a ansiedade, as nostalgias e os temores causados pelo que virá, e por isso enaltece a imagem divina como possibilidade de alento:

Eu não tenho de ti mais do que uma imagem vaga e misteriosa, como aquelas com que a alma, empenhada em rasgar o véu estrelado do mistério, pode representar, em seus êxtases, o esplendor do Divino. Mas sei que virás; e de tal modo como o sublime difamador das Blasfêmias condena e injuria o anunciador da futura fé, antes que ele tenha aparecido sobre a terra, eu te amo e te bendigo, profeta por que ansiamos, sem que o bálsamo reparador de tua palavra tenha descido sobre nosso coração. (Rodó, 1957:150). 
Conforme María Belén Morales (1990), Rodó faz do retorno profético de Cristo um fundamento de um tema literário. Para a autora, há um caráter eclético e labiríntico dos processos estéticos "finisseculares": o revival, que do presente se volta ao passado, resgatando elementos simbólicos e místicos do fundo histórico, que retorna à contemporaneidade sem querer renunciar a nenhuma das temporalidades. Talvez também se pudesse interpretar como a busca de uma filosofia capaz de oferecer um futuro para aqueles que sentem suas crenças idealizadas sucumbir a apenas algo objetivo e material:

De todas as rotas temos visto voltar os peregrinos, assegurando-nos que somente têm encontrado diante de seu passo o deserto e a sombra. Do que nos falarás, revelador, para que encontremos em tua palavra a vibração que incita a fé, e a virtude que triunfa da indiferença, e o calor que reduz o fastio? (Rodó, 1957:149).

As ideias de fé e esperança messiânica eram vistas por Rodó como indispensáveis para esses tempos vividos. Aí se pode notar também uma espécie de contraposição entre a figura do peregrino e a do cidadão. No caso, o primeiro representa a busca de um sujeito individual, que empreende longas jornadas em busca da fé; a alusão rodoniana no trecho citado é justamente a esse sujeito, e não ao cidadão orientado pela razão e por princípios coletivos que buscam um bem-estar social. É interessante apontar que esses são os primeiros escritos de Rodó, daí a mistura dos influxos esteticistas que vinham da Europa, do romantismo, bastante associado ao catolicismo, para formular uma percepção desse momento que seu país e continente vivenciavam.

O modernismo surgiu com o desenvolvimento das técnicas e da ciência que provocaram uma mudança muito sensível dos fatores socioeconômicos, bem como uma revisão das ideologias oficiais. Segundo Sarah Bollo (1976), Rodó pode ser visto como a consciência crítica do modernismo hispano-americano por afirmar que muitas vezes esse movimento na América Latina não passou de superficialidades:

Nosso modernismo passou apenas da superficialidade. Temos, sim, colorações raras, ritmos exóticos, manifestações de um vivo afã pela novidade do aparente, ousadas aventuras no mundo da harmonia e o mundo da imagem, refinamentos curiosos e sibaríticos da sensação... No entanto, o sentimento demonstrou apenas conhecer as novas fontes da emoção espiritual, e o pensamento dorme na sombra, o que segue os 
rumos desconhecidos, ou representa somente a manifestação de algumas individualidades isoladas, o vão em que se perde a voz de espíritos sem séquitos. (Rodó, 1957:157).

Essa variedade de tendência, cujo tom era futurista, era vista pelo pensador uruguaio como inconsistente. Nesse sentido, observa-se uma espécie de herança romântica nos autores hispano-americanos do final do século XIX. Enfatizam a solidão dentro da multidão, a sensação de dispersão nas urbes, provocando desorientação e desconfiança perante o novo.

A respeito do modernismo na Espanha, alguns críticos, como Salinas (1970), costumam impor uma separação entre a geração espanhola de 1898 e o modernismo. Entretanto, Azam aponta que, longe de serem opostos, estão em estreita comunicação; ambos os movimentos se preocupam com a constituição da identidade nacional e cultural:

As reações diante da crise são numerosas e variadas: o desejo de uma reforma radical da vida espanhola inspira soluções de tipo social, jurídico e econômico que, em alguns casos, conduzem à rejeição de uma política de abstração e ao estabelecimento de novas estruturas agrárias, industriais e comerciais; em outros casos, desembocam no vasto movimento ideológico e estético cujas profundas ressonâncias afetam a cultura nacional. (Azam, 1989:73).

Azam ressalta que os jovens escritores agrupados na Geração de 1898 são afetados por uma crise não apenas política, mas ideológica e estética. Sofrem uma crise de religiosidade em sua juventude e um afastamento da ortodoxia católica. Partem de posições radicais - anarquismo e socialismo fundamentalmente - e deságuam na tragédia. Perdem a fé na razão e na ciência, e as categorias racionais cedem lugar à sensação e à intuição, ao mesmo tempo que surge uma intensa preocupação com a morte e com o passar do tempo.

Dessa forma, a modernidade significava um ataque à Espanha tradicional católica, a qual é culpada de muitos "males". Assim como Rodó realizara aquilo que chamamos de "balanço" da crise de fim de século, Unamuno o fizera na Espanha, também resgatando os modelos gregos a fim de se fundamentar em modelos universais já consagrados. Em seu diário íntimo, confessa: 
Padeço de uma decomposição espiritual, uma verdadeira pulverização sob a qual palpita a vontade da minha mente, seu forte desejo de acreditar, de acreditar em si, no que não aniquila (Unamuno, 1998:21).

O ano de 1890 é reconhecido pela fortuna crítica de Unamuno como a década de sua grande crise espiritual e religiosa. O tema do misticismo aparece em sua obra de forma constante e era, em sua concepção, um ponto fundamental para a formação da nação espanhola. $\mathrm{O}$ autor percebia que a modernidade europeia se assentava em um rigor científico muitas vezes dogmático, por isso engendrava fantasmas doutrinários, intelectuais e científicos.

Em seu texto "La eterna tradición", de 18957, Unamuno (1968b) discute os dilemas da modernização espanhola sob a perspectiva da perda das tradições do que denomina de "invasão europeia". A explicação da ciência assustava a geração em questão, particularmente Unamuno:

\begin{abstract}
Alguns pedem ciência e arte espanholas, e este é o dia em que, depois de ouvi-los calmamente, não sabemos bem o que é isso... A ciência é chamada de tantas coisas; e a arte, de outras tantas! Os jornais afirmam que a ciência diz isso ou aquilo quando um homem fala, como se a ciência fosse um espírito santo, e, embora ninguém, se parar para pensar, acredite em tão grosseira blasfêmia, as pessoas não param ordinariamente para pensar, e os disparates se arraigam na impunidade. Os mais atrozes, aqueles dos quais todos se distanciam, se são vistos desnudos, servem como base para raciocinar sobre todos, dão vida a argumentos pseudorracionais que, por sua vez, engendram violências e atos de selvageria. (Unamuno, 1968b:19).
\end{abstract}

Para Marrero (1960), a particularidade de Unamuno é querer fazer de Cristo um mito ou ao menos explicá-lo dessa forma, forjado pelo homem; no caso, pelo homem espanhol. A Espanha é analisada como pátria, como realidade histórico-cultural e como convergência de valores espirituais.

Nesse sentido, o debate trazido com o modernismo, do "regeneracionismo", desenvolvido entre 1890-1910, é um debate que envolveu a teologia e a ciência, a Igreja e o mundo. A denominação "modernismo" vem sugerida de heterodoxia, uma vez que muitos preceitos foram revistos, como a hierarquia, a relação Igreja-Estado, o dogmatismo ou a participação dos católicos na vida pública. 
Após 1897-1898, segundo López (1984), Unamuno faz uma conceitualização mística da Espanha, momento em que elabora sua formulação sobre o casticismo amparado na ideia de tradição eterna. $\mathrm{O}$ termo "intra-história", cunhado pelo pensador, foi uma das primeiras críticas ao formalismo da falsa história, das guerras, dos reis, governos e acontecimentos aparentes. Seria um dos primeiros passos para o estímulo do protagonismo popular no "que fazer" histórico. Por isso, representa um mínimo de tomada de consciência de diversos intelectuais, um ângulo de enfoque evidentemente novo no plano das ideias. Segundo Unamuno,

faz algum tempo que se iniciou a europeização da Espanha; as traduções pululam de dar gosto; entre algumas pessoas, lê-se mais o estrangeiro do que o nacional, e os críticos de mais autoridade e público vêm apresentando literatos ou pensadores estrangeiros. Alguns dizem que têm feito, nesse sentido, mais pela cultura nacional que qualquer outro, abrindo-nos o apetite para iguarias de fora, servindo-nos mais ou menos preparadas à espanhola. (1968b:15).

Nesse mesmo artigo, Unamuno afirma que até Menéndez y Pelayo (1856-1912), "o espanhol incorrigível", vem apresentando a cultura europeia contemporânea. O programa de alguns autores "abria as portas" para o exterior, apostava nas influências estrangeiras, na reconstrução e na europeização do país.

\section{O EQUILÍBRIO ENTRE DEUS E CIÊNCIA}

Para Maria Belén de Castro Morales (2008), uma das grandes tendências que marcaram o ensaio do século XIX e o início do XX foi a continuidade do pensamento positivista, que, com sua ilusão progressista, baseada na razão empírica, fazia uma análise dos problemas hispano-americanos à luz de princípios científicos, materialistas e deterministas, entre os quais se ressaltam as nefastas teorias sociológicas e raciais sobre a inferioridade dos povos mestiços e das nações latinas.

Apesar da imensa influência que a corrente positivista de pensamento teve na Hispano-América, neste texto interessa debater como Rodó e Unamuno percebiam um dos grandes dilemas que essa corrente impunha: a razão científica superaria as explicações místicas? Ou seja, a grande desorganização social vivenciada na crise de fim de 
século, que muitos atribuíram somente a fatores materiais, não seria também de ordem espiritual?

O positivismo não era a corrente de pensamento exclusiva, mesclava-se a outras, em um turbulento e contraditório ambiente intelectual. De acordo com Ardao (1968), em sua obra Espiritualismo y positivismo en el Uruguay, o espiritualismo e o positivismo foram algo além de duas instâncias do pensamento uruguaio. Protagonizaram um verdadeiro "drama filosófico" que se apresentou perante sua maior crise histórica e constituíram-se definitivamente como entidade social. Em curto período de duas décadas, notam-se, em "nosso pequeno mundo histórico", as duas grandes crises espirituais do homem moderno: a da fé, típica do século XVIII, e a da razão absolutista, típica do século XIX.

Na Espanha, para Abellán (1964), o positivismo filosófico adquiriu protagonismo, em meados do século XIX, mediante um triplo confronto: 1) em face da escolástica como cosmovisão católica do mundo espanhol, emergindo uma filosofia laica e secularizada, representada pelo positivismo; 2) diante da moral religiosa e espiritual do catolicismo, propõe-se uma moral natural e laica, baseada em princípios científicos; 3) em face da cultura da pobreza, exaltam-se a industrialização e o desenvolvimento econômico e outras formas do pensamento anglo-saxônico.

Nesse sentido, grande parte das discussões tratadas por ambos os autores segue em busca de uma "restauração" ou "instauração" de uma ordem moral e intelectual a fim de que um novo modelo de organização ideal surja para a sociedade moderna. É interessante pensarmos que tanto Rodó quanto Unamuno depreciavam a concepção positivista que pretendia substituir a religião pela ciência, como se pode observar a seguir: "Não, nunca estive apaixonado pela ciência, sempre busquei algo por trás dela” (Unamuno, 1968b:115). Para o crítico espanhol, a ciência retira a sabedoria dos homens e costuma convertê-los em fantasmas carregados de conhecimento.

Segundo Alberich (1959), Unamuno deprecia a concepção positivista que pretendia substituir a religião pela ciência, entretanto, por mais que atacasse constantemente tal corrente ao longo de sua obra, sofreu bastante sua influência. Desde 1895, o autor começa a manifestar um interesse pelo cientificismo, por isso sua linguagem metafórica era permeada de termos biológicos, geológicos e evolucionistas: 
Se todas as ciências pudessem fazer uma álgebra universal, se pudéssemos evitar, na economia política, as nocivas palavras de valor, riqueza, renda, capital etc., tão cheias de vida mas tão corrompidas pelo pecado original, uma álgebra lhes serviria de batismo, uma vez que extrairíamos ciência de seu fundo histórico, metafórico. (Unamuno, 1968b:22).

Nessa passagem, pode-se perceber o uso de metáforas religiosas presentes em sua reflexão sobre a ciência. Também se observa que Unamuno não desvinculava uma esfera da outra; dizia que a religiosidade é parte integrante da cultura, portanto, inseparável de qualquer exercício analítico e científico. Sua filosofia pretendia responder à necessidade de formular uma "concepção unitária" entre ciência e deus/religiosidade, objetivo e subjetivo, e misticismo e realismo: "Na religião, unificam-se a ciência, a poesia e a ação" (Unamuno, 1998:27). Em outro importante texto, "La tiranía de las ideas", de 1899, Unamuno (1968b) questionou a existência de uma ideologia rígida, inalterável, praticada por homens cuja pretensão era abrigar verdades absolutas.

Na mesma direção, Rodó apontou:

Foi esse um empirismo utilitarista de voo muito baixo e de capacidade muito mesquinha, como se feito para agradar, com sua aparente claridade de ideias e com a limitação de seus alcances morais e sociais (1957:148).

Como se pode observar em suas últimas obras do decênio do século XIX e também em sua obra mais conhecida, Ariel, publicada em 1900, Rodó tratou o dilema da ciência como substituta absoluta da religiosidade de modo constante:

$\mathrm{O}$ amor religioso por uma arte ou uma ciência pode originar, nos que o levam infundido nas entranhas, extremos de veneração supersticiosa, que reprimem o impulso da vontade, mediante o qual aquele amor se faria ativo e fecundo; e, desse modo, militam, paradoxalmente, entre as causas que concorrem para o malogro da vocação. (Rodó, 1957: 371).

Nesse trecho, pode-se perceber uma crítica rodoniana com relação ao excesso de fanatismo por qualquer ideia, seja de origem religiosa, seja de origem científica; nesse caso, o amor à ciência deveria ser comedido, repleto de dúvidas saudáveis. No prólogo ao livro Idola Fori, do 
colombiano Carlos Arturo Torres, escrito em 1910, Rodó demonstra clara consciência sobre a situação em que se dissolvia o positivismo na intelectualidade latino-americana, temática amplamente debatida em sua obra Motivos de Proteo (1909). Além disso, perguntava-se de que maneira, quando não acompanhada do idealismo, poderia ser uma ideologia interpretada de modo estreito. Pondera que o positivismo teve grandes pensadores, como Comte, Spencer, Taine e Renan, cuja qualidade de pensamento é inegável, porém, na América Latina, houve uma "interpretação estreita e pobremente baseada na prática" (Rodó, 1957:503) ${ }^{9}$. Esse processo ideológico descrito por Rodó faz parte de uma herança do papel que o positivismo desempenhou na América Latina justamente em um momento em que as doutrinas cientificistas e materialistas debatiam com os dogmas da Igreja católica.

Em outro texto, Liberalismo y jacobinismo, no qual também discute os temas religião e ciência, Rodó (1957) afirma que Spencer, um dos representantes máximos da ciência, reconhece que são assuntos distintos mas não irreconciliáveis, pois pertencem ao mistério infinito ${ }^{10}$. Unamuno diz sobre Spencer que um de seus grandes ensinamentos é que o conhecimento científico se torna mais organizado quando passa da dimensão qualitativa para a quantitativa. Nas palavras de Alberich:

E isso explica que, ao reagir contra seu primeiro positivismo, nosso escritor abomina o 'engenheiro filosófico' e conserva, em contrapartida, uma cordial veneração por aquele santo e sábio homem chamado Darwin (1959: 68).

Ainda segundo Alberich, Unamuno diferenciava o significado da obra de Spencer da de Darwin; este seria um homem religiosamente científico, e Spencer cientificamente religioso. O primeiro se aproxima da ciência com a devoção e a suprema sinceridade que deve ter a busca da verdade. O segundo, ao priorizar a esfera científica, relegando o mundo religioso, trata o transcendente como um matemático, como um resíduo depreciável e desnecessário para seus cálculos.

É interessante pensar que a perspectiva da importância da religião cristã já havia sido sinalizada por Auguste Comte quando este afirma seu papel no processo civilizador: a religião teria reunido todos os homens pela crença em um só Deus e pelo dogma da "fraternidade universal". Por isso, foi possível organizar uma sociedade mais vasta e reunir todos os povos em uma "família comum". 
Esse papel atribuído à religião é de grande importância para se pensar como os autores em questão concebiam os laços sociais criados nessa esfera. Unamuno e Rodó estavam diante do crescente protagonismo da Ciência e da Razão; os dogmas religiosos e suas experiências passavam por questionamentos de facções progressistas dentro do catolicismo, cujo objetivo era "modernizar" para não perder o ritmo dos novos tempos.

Ambos os pensadores se autodefiniam como críticos dos dogmas petrificados da Igreja e cultivavam diversas dúvidas e inquietudes religiosas. Em carta bastante significativa endereçada a Rodó em 13 de dezembro de 1900, Unamuno afirma:

Culmina, a meu ver, o espírito latino no catolicismo, de tal forma que mesmo os livres pensadores latinos são católicos sem sabê-lo. Essa concepção social e estética da religião é profundamente latina (Renan era um católico malgré soi; basta ver sua posição diante de Amiel), e eu me sinto protestante no mais íntimo do protestantismo (Harnack, Ritschl, Hermann etc. me convenceram disso). Podem parecer análogos um positivista ou um panteísta latino e outro germânico, mas, aprofundando-se no ideal, chegamos ao sentimento e ao modo de sentir o mundo e a vida, a ponto de vermos que um segue sendo católico, e o outro protestante, depois de ter recusado todo o dogma de uma e de outra crença. (1957:1306).

Em El drama religioso de Unamuno, Benítez (1949) afirma que Unamuno almejava ser um grande espanhol, mas não queria ser um católico rigoroso, não pelo catolicismo em si, mas por uma crítica ao Vaticano e aos clérigos espanhóis. No decorrer de sua vida, sempre professou uma religiosidade sui generis, que negava o ateísmo. Em "El espíritu castellano", reconheceu os laços sociais da Espanha com a religião católica, porém não deixou de questionar as guerras cujas justificativas eram religiosas:

Em tais sociedades, o mais íntimo laço social é a religião, e com ela uma moral extrema de lex, de mandato, que engendra casuísmo e métodos para ganhar o céu. De todos os países católicos, talvez o mais católico tenha sido nossa Espanha castiça [...]. Que as castiças guerras de nossa idade de ouro foram pela religião... Esta era o laço social, e a unidade religiosa forma suprema do social. Para demarcar, por meio da remoção, a unidade nacional expulsou os judeus e os mouros, e fechou a porta para os luteranos por "sublevação, perturbação da república". Ordens 
militares religiosas foram fundadas na Espanha para a cruzada interior que reconquistou o próprio solo, e em nenhuma parte o mais vivo sentimento de irmandade entre o sacerdote e o guerreiro do que na região que deu tantos padres guerrilheiros afrancesados. Guerras religiosas, sim, enquanto o reino da religião se estende a este mundo, na qualidade de instituição para o sustento da máquina social e para a manutenção da ordem e do silêncio, e da obediência à lei. (Unamuno, 1968b:93-95).

Escrito em 1895, “El espíritu castellano" é sucedido por outro texto, "El reinado social de Jesus", de 1897, em que Unamuno tencionou conciliar o socialismo econômico e científico com o cristianismo. $\mathrm{O}$ cristianismo aparece nessa obra vinculado ao socialismo, em relação direta de subordinação e de respeito. A solução do problema social seria o pré-requisito para recolocar cabalmente o problema religioso como o centro das relações humanas e sociais:

Creio firmemente que o fim das nações enquanto tais está mais próximo do que se poderia pensar - o socialismo não trabalha em vão - e convém que cada uma delas se prepare para contribuir com o acervo comum dos povos com o mais puro, ou seja, o mais cristão de cada uma (Unamuno apud León, 2001: 108).

Nesse mesmo texto, Unamuno faz uma crítica ao patriotismo espanhol e afirma que a Espanha é o país que se valoriza por ser o mais religioso, porém poucos sabem ler o evangelho, e a ignorância é geral, mesmo entre os teólogos. Para ele, tratava-se de um erro opor o socialismo ao cristianismo e ao catolicismo do povo espanhol. Segundo León, "Unamuno concebe o porvir da Espanha como inextrincavelmente unido ao dos outros povos do mundo, em sua marcha inexorável rumo a um futuro de 'irmandade cristã' dos povos" (2001:105). Para Unamuno, o progresso consistia na cristianização dos povos, na "ascensão da linhagem humana" ao reino da paz e da caridade cristãs, sendo que a tarefa do socialismo seria acabar com a sociedade burguesa sustentada no militarismo e transformá-la em uma sociedade industrial pacífica: "Socialismo e comunismo. O sagrado comunismo da comunicação, a participação de todos de um mesmo Deus; a comunhão em espírito" (Unamuno, 1998:20).

Anos mais tarde, em 1924, vai afirmar, em La agonía del cristianismo (Unamuno, 1938), que não é missão cristã resolver o problema econômico social da pobreza e da riqueza, da divisão de bens da terra, 
entretanto Cristo chama a todos igualmente, mesmo reconhecendo que sempre haverá pobres entre os homens.

Em seu texto de crítica literária da obra Nuevos ensayos de crítica literaria y filosófica (publicada postumamente), de Alberto Nin Frías, Rodó afirma sobre a ortodoxia religiosa: “Compreendo e aplaudo o fundamento cristão; mas não se justifica o apego a dogmas que constituem um grande 'impedimento' para a propaganda racional [...]". (1957:978).

Segundo Zaldumbide (1951), Rodó acreditava que a eficácia de uma arte redentora era pregar o amor, a beleza, a virtude do belo: "Permitir sentir o belo é obra de misericórdia" (Zaldumbide, 1951:14). Seu afã seria "falar com verdade das coisas", e isso para o crítico era um empenho de apóstolo.

Em "Liberalismo y jacobinismo" (1906), Rodó afirmou que o sentido histórico do século XIX buscava se orientar pelo pensamento crítico, porém sob os lemas da tolerância e da amplitude. Adicionado a isso, o sentido da obra intelectual desse século seria a tolerância, sobretudo a espiritual. Nessa obra, Rodó expressa o cuidado com a situação da moral laica, que proibia a demonstração da religião por meio de seus símbolos e imagens. É nessa obra que se pode perceber a defesa do autor uruguaio a símbolos da Igreja católica. Foi uma reação à medida para retirada dos crucifixos dos estabelecimentos que estavam sob a administração da Comissão Nacional de Caridade e Beneficência em 1906. A medida foi aprovada como resultado natural da expansão dos ideais liberais. Rodó, que se considerava um liberal, demonstrou-se contra. Em carta datada de 1906 ao jornal La Razón, sustentou que a eliminação dos símbolos da Igreja não era um ato próprio do regime liberal, mas sim de um regime jacobino. A retirada de Cristo das paredes seria uma separação entre o passado e o futuro:

As instituições que ficaram para trás no movimento, que ficaram para trás no movimento da civilização e que somente agora representam uma tradição digna de respeito - e, em sua persistência militante, uma força regressiva -, tiveram sua razão de ser e seus dias gloriosos, e prestaram grandes serviços ao progresso do mundo; e é precisamente no terreno da história que menos podem se tornar vulneráveis. (Rodó, 1957:251) 
Para Rodó, Jesus Cristo representa a nossa civilização, e no mundo significa o fundamento da caridade, e isso se opunha aos argumentos históricos. Jesus é visto como um grande reformador moral, e não como um líder religioso, e essa era a grande justificativa para sua permanência nos estabelecimentos. Além disso, o autor dizia que não tinha dificuldades de se assumir como herdeiro moral do cristianismo.

Nesse ponto, pode-se perceber, novamente, grande influência do pensamento comtiano em Rodó. Comte (1978), na lição 54 do curso sobre o catecismo positivista, afirmou que Jesus Cristo, o "fundador do catolicismo", permitiu que a doutrina católica se estabelecesse como a origem do poder espiritual. Além disso, seria completamente autônoma e dotada de uma genealogia própria e independente do poder temporal. O catolicismo ensinou a "moral universal" e, pela primeira vez na história da humanidade, um sistema social poderia combinar perfeitamente com um sistema moral universal.

É interessante apontar que Unamuno, em La agonía del cristianismo, cita Comte com o objetivo de sair em defesa da religião católica: "Augusto Comte pedia que 'os que creem em Deus se façam católicos'" (1938:56).

Conforme mencionado, Rodó era um grande defensor das tradições do passado. Segundo o autor uruguaio, tanto o presente quanto o futuro se alimentariam dessas tradições. A elegância grega e a fraternidade cristã seriam exemplos de tradição a serem mantidos. Para Rodó, nem se o crucifixo representasse exclusivamente o catolicismo - que prevaleceu na Europa e definiu as nacionalidades europeias deveria ser retirado das paredes.

Miguel de Unamuno e José Enrique Rodó foram pensadores que registraram em seus textos a questão religiosa ao mesmo tempo que viveram os auspícios do cientificismo, a crise de fim de século, bem como a crítica à Igreja católica. Contudo, não deixaram de perceber a religiosidade como parte integrante dos estilos de vida dos povos da Hispano-América. As mudanças ocorridas na forma de encarar essa esfera serviram para a compreensão do movimento de secularização da sociedade. 


\section{A HETERODOXIA RELIGIOSA}

A preocupação de Rodó e de Unamuno com a heterodoxia religiosa foi discutida nas correspondências trocadas em que o assunto comum era a harmonia espiritual da raça espanhola. Em carta de 20 de outubro de 1902, Rodó afirma a Unamuno:

Quanto eu desejo que sua prometida obra sobre a Religião e a Ciência apareça o mais rapidamente possível! Me preocupa com muita intensidade o problema religioso e leio com interesse tudo o que espero que possa me dar nova luz sobre isso (Rodó, 1957:1312).

Em resposta a essa recomendação rodoniana, Unamuno responde em 7 de fevereiro de 1903:

Minha obra Religião e Ciência caminha muito pouco a pouco. Agora leio o grande pensador e psicólogo norte americano William James, cujo livro As variedades da experiência religiosa me parece magistral, assim como seus ensaios $A$ vontade de acreditar (que é como ele intitula o primeiro deles). São obras que creio seguramente que interessarão a Nin Frías, a quem, em meu nome, as recomendo. (1957:1313).

Nessas passagens, está presente a preocupação de ambos com o sentimento religioso naquele momento. Suas reflexões são poéticas, mas também são apostas teóricas sobre o assunto. Desse modo, a perspectiva desses pensadores sobre a questão religiosa não é precisamente a vibração visceral de um fervoroso cristão diante de sua fé, mas envolve os conflitos internos e externos que vivenciavam naquele instante, além da percepção de que a modernidade traria inevitavelmente como característica um processo de secularização, uma diferenciação estrutural dos espaços sociais, e, por fim, a Igreja teria sua importância reduzida. O grande desafio era pensar considerando essa nova lógica e onde encontrariam repouso para as profundas inquietações:

O que faz a comunidade do Povo senão religião? O que os une sob a história, no curso escuro de seus humildes trabalhos cotidianos? Os interesses não são mais do que a aparente ligação da aglomeração, o espírito comum é dado pela religião. A religião faz a pátria e é a pátria do espírito. (Unamuno, 1998:20). 
Pode-se ler em Unamuno uma intepretação sobre a religião que pretende resgatar o significado perdido da espiritualidade na nova sociedade. De certa forma, realiza uma análise histórica da dimensão do fenômeno religioso cujo significado é a união, a aglomeração, a comunidade e, por fim, a pátria.

De acordo com María Belén de Castro Morales (1990), ao lado do problema metafísico e existencial que transparece na preocupação religiosa de Rodó, percebe-se, em sua reflexão sobre o cristianismo primitivo, uma vertente esteticista que dá plasticidade, uma "bela envoltura" ao conteúdo ético da doutrina evangélica.

Foi no cristianismo primitivo, ainda impregnado do clima helênico, que Rodó encontrou um motivo simbólico capaz de coadunar os elementos éticos, vitais, impregnados de juventude e força expansiva de uma carga estética e pura. Rodó constantemente retoma o imaginário do mundo grego como o centro da origem perdida, daí a necessidade de superar o vazio metafísico ocasionado com o processo de modernização destruidor do princípio conciliador do materialismo e do espiritualismo.

Unamuno também não suportava as intolerâncias dogmáticas e ortodoxas, sobretudo aquelas que oprimiam as consciências religiosas. Segundo ele, o progresso humano consistiria na cristianização dos povos, na ascensão da linhagem humana ao reino da paz e da caridade cristãs.

Para Marrero (1960), as obras de Unamuno expressam de modo contundente seu pensamento místico. $\mathrm{O}$ cristianismo seria um valor do espírito universal, que tem suas raízes no mais íntimo da individualidade humana. Por se tratar de um problema estritamente individual, é universal. A religião estaria a serviço da necessidade do instinto de conservação pessoal. Segundo Unamuno (1938:13),

O cristianismo é um valor do espírito universal que tem suas raízes no mais íntimo da individualidade humana. Os jesuítas dizem que com o cristianismo se pode resolver o negócio de nossa própria salvação individual e pessoal, e, embora sejam os jesuítas quem em especial o digam, tratando o divino como um problema de economia, temos de aceitá-lo aqui como um postulado prévio. 
Unamuno também fazia referências aos modelos gregos, e isso implicava o propósito de se fundamentar em modelos universais já consagrados. São variadas as funções que desempenham a retomada da tradição greco-latina em sua obra, entre elas sua sobrevivência como matéria literária, além de servir como revestimento erudito e humanístico. Seu conhecimento sobre os clássicos gregos era muito aprofundado. Ensinou literatura grega na Universidade de Salamanca, e uma pluralidade de cânones foi registrada em sua poesia:

Em consonância com as variadas referências mitológicas - que adotam o discurso de certo prurido livresco e erudito -, prevalece um destacado pilar no que concerne ao tratamento unamuniano da tradição clássica (Borrego, 2008: 28).

Quando Unamuno escreve os artigos que resultaram na obra La agonía del cristianismo, assim como Rodó, constatava que a sociedade mata a cristandade, pois esta seria algo de solitários. Nesse sentido, pode-se perceber um momento marcado por extrema ambiguidade, e por isso a reflexão sobre a simultaneidade de esferas que muitas vezes não se coadunam - campo e cidade, comunidade e sociedade, ideia e emoção, o sacro e o profano - faz parte do universo do intelectual, uma figura que também é indefinível ${ }^{11}$.

Nessa obra, escrita em $1924^{12}$, Unamuno afirma expor "a agonia e a luta pelo cristianismo em sua vida íntima". Atesta que o termo muitas vezes pode ocasionar certa confusão, pois o sufixo "-ismo", de cristianismo, leva a crer que se trata de uma doutrina, como platonismo, aristotelismo, cartesianismo, kantismo, hegelianismo. No entanto, segundo sua visão, não se trata disso. A palavra cristandade significaria a qualidade de ser cristão, como humanidade a de ser homem, designando o conjunto dos cristãos, portanto não deve ser confundida com uma doutrina.

É importante ressaltar que o tema da religião aparece com força nas análises sociológicas de Max Weber, afirmando que, ao se elegerem as religiões como objeto, se produzem uma sociologia geral da mudança social como inevitável racionalização da vida e uma sociologia específica da modernização ocidental. A respeito desse processo em Weber, Pierucci (2003:19) afirma: "Antes de mais nada, uma busca como esta em Sociologia da Religião deve e quer ser ao mesmo tempo uma contribuição à tipologia e sociologia do próprio racionalismo". 
Também em Durkheim (1971) lemos análises sobre a questão da vida religiosa na modernidade. Em $A$ educação moral, o autor afirma que não bastava suprimir a religião; era necessário substituí-la. Ela teria como objetivo funcionar como cimento de uma nova sociedade. Para tanto, a moral deve revestir-se de uma aurora religiosa por mais que não fosse revelada.

O tema religioso, que se reverteu em uma temática literária das obras do final do século, não está, portanto, atrelado à irracionalidade ou à magia; ao contrário, mostra-se calculado e racionalizado, presente nas manifestações de setores progressistas da Igreja, uma vez que tentava acompanhar os passos dos métodos científicos do conhecimento.

\section{CONSIDERAÇÕES FINAIS - POR UMA CONCEPÇÃO DA PERSONALIDADE INTEGRAL}

Tanto Rodó quanto Unamuno pensaram a questão religiosa considerando as especificidades de seus contextos sociais e culturais, portanto o tema não poderia ser visto apenas como uma extensão do mundo europeu, mas sim pela percepção da singularidade que marcou o processo de secularização de suas respectivas sociedades.

Segundo Monegal (1957), Rodó sente uma inquietação religiosa, quase mística, apesar do esteticismo e do decadentismo que almejava combater. Essas características poderiam ser encaradas como sintomas dos percalços daqueles que tentaram aderir a alguma modernidade por meio de "terrenos atrasados", ou seja, Rodó pretendia, para as antigas colônias ibéricas, uma adesão ao pensamento elaborado europeu alimentado por Espanha e Portugal. No entanto, conforme se buscou demonstrar pelo pensamento unamuniamo, a Espanha também não se mostrava satisfeita com sua posição de "atraso" no continente europeu, daí a procura incessante pela regeneração, que objetivava, de certo modo, forjar uma nova nação espanhola.

A busca rodoniana por uma cultura legitimadora das práticas sociais e culturais e das instituições parece seguir sempre a alternativa de um retorno às heranças espanholas, mas essa reciprocidade não é sinônimo de igualdade, ou seja, o Uruguai, assim como qualquer país hispano-americano, nunca seria igual à Espanha. Portanto, a América Hispâ- 
nica é exemplo de que o trânsito linear e unidirecional entre a tradição e a modernização não existe, a não ser na cabeça de alguns ideólogos.

Por sua vez, Unamuno, em sua juventude, escreveu em quase todas as revistas radicais da Espanha, fazia parte de um grupo que iniciava uma "ruptura" estética e ideológica da "gente nova" - regeneracionistas, modernistas, noventayochistas - contra a "gente velha" - acadêmicos, heróis do realismo, poetas oficiais e demais filhos da Restauração -, ao mesmo tempo que sentia a insegurança da abertura espanhola para a chamada "razão instrumental". A reação de Unamuno a tal situação pode ser chamada de neoespiritualista, uma vez que abria espaço para a reflexão dos valores humanísticos e tecia uma grande crítica à ortodoxia da Igreja católica.

O que se pode depreender do processo de modernização e do que deságua na questão religiosa de Miguel de Unamuno e de José Enrique Rodó é que ambos tentaram realizar uma análise da temática que também se desdobrou de forma estética em seus textos. Analisaram de modo bastante contundente a conjuntura em que viviam e, de certa forma, apostaram na recusa de um progressismo científico sem critérios, que, conforme suas concepções, matava as tradições.

A religiosidade e o pensamento místico foram apontados por Unamuno como parte da essência do povo espanhol, portanto merecia uma análise acurada. Apostando na ideia de intra-história, da tradição histórica do povo e da totalidade, dizia que os livros deveriam falar como homens, e não os homens deveriam falar como livros, ou seja, a palavra escrita somente seria importante se estivesse relacionada à vida das pessoas. Desse modo, a arte e a vida estavam intrinsecamente unidas.

Em Rodó, o que podemos interpretar é também uma ideia de equilíbrio constante entre corpo e espírito. Se a América Hispânica era herdeira direta da Espanha, o tema da religião também fazia parte de sua essência. Nesse sentido, saiu em defesa da moral cristã, acreditava na ideia de que a civilização deveria ser harmônica e regida por um princípio espiritual. Seus textos, escritos na forma de ensaios, têm caráter comunicativo entre autor e escritor, refletem sobre o tempo presente apoiados na sólida base do passado e seguem um implícito desejo de antecipar o futuro pela compreensão do momento presente. Conforme Gómez-Martínez (1981), o ensaísta pensa obrigatoria- 
mente as circunstâncias do presente vivido, sendo essa a verdadeira função do ensaio.

Assim, o tempo contemporâneo a eles impunha uma série de questões vitais. A tônica era dada por uma mescla de pensamentos, correntes filosóficas e contradições, sendo o dilema mais importante da crise de fim de século a ideia da separação entre a ciência e a religião. Conforme visto neste artigo, as reflexões dos autores tratados aqui giraram em torno dessa temática; analisaram a descontinuidade desse processo, as mudanças que afetavam as diferentes concepções do pensamento e chegaram à conclusão de que a personalidade humana estava sendo diminuída, empobrecida e esmagada pela modernidade.

No entanto, em alguma medida, não deixaram de vivenciar uma das primeiras promessas libertadoras da modernidade: a dessacralização perante as esferas da vida, uma vez que questionaram a autoridade no pensamento e na sociedade, incentivaram a liberdade de pensar e de conhecer, de duvidar e de questionar, enfim, expressaram e comunicaram suas inquietações.

(Recebido para publicação em 23 de fevereiro de 2016)

(Reapresentado em 10 de outubro de 2018)

(Aprovado para publicação em 27 de março de 2019) 


\section{NOTAS}

1 Conforme Phelan (1993), a origem do termo América Latina foi concebida na França, durante a década de 1860, como um programa de ação para incorporar o papel francês no continente. Um dos primeiros a propagar o programa panlatino foi o economista francês Michel Chevalier (1806-1879), que viajou de modo extenso por Estados Unidos, México e Cuba, e foi responsável pela ideia de que a França constituiria o canal interoceânico no Panamá em 1844. Em 1855, Chevalier constituiu um programa geoideológico que poderia servir como uma racionalização para a expansão econômica da França tanto na América quanto no Extremo Oriente. Ele estava preocupado com o isolamento diplomático francês causado pela decadência progressiva das nações latinas; seu virulento antianglosaxonismo estava concentrado exclusivamente contra os Estados Unidos. A tese de Phelan foi muito criticada por outros pensadores, como Rojas Mix (1991) e Ardao (1980). Para o primeiro, a história da identidade latinoamericana é também a história dos diversos nomes da América e das razões pelas quais esses nomes foram impostos. O próprio termo foi forjado por intelectuais hispano-americanos. Quando se fala em América Latina, não levamos em consideração os povos originários da região, nem os povos africanos trazidos forçosamente para cá durante séculos, nem consideramos somente a perspectiva de uma dominação que não os compreende como agentes do processo de formação de identidade do continente. Rojas Mix sublinha que, se durante a colônia o americano admite ser chamado de "criollo", "indiano" ou "espanhol das índias", no começo do século XIX o problema da identidade se apresenta sob um novo aspecto: atrelado aos processos emancipatórios, cuja necessidade era a imposição do nome americano.

2 Expressão utilizada por vários autores espanhóis e latino-americanos que analisaram o período: Venegas (1998), Alfonso Morales (1992), M. B. de C. Morales (2008), Azúa (2001), entre outros.

3 Além de Miguel de Unamuno, entre seus principais correspondentes estão: Leopoldo Alas, Salvador Rueda, Rafael de Altamira, Rubén Darío, Leopoldo Lugones, entre outros.

4 Carlos Reyles (1868-1938), Carlos Vaz Ferreira (1872-1958), Herrera y Reissig (19751910), Delmira Agostini (1886-1914), Florencio Sánchez (1875-1910) e Horacio Quiroga (1878-1937).

5 Antonio Machado (1875-1939), Azorín (1873-1967), Angel Ganivet (1865-1898), Pío Baroja (1872-1956), entre outros.

6 No caso brasileiro, um pensador que podemos citar como grande exemplo da retomada do pensamento hispânico foi o pernambucano Gilberto Freyre (1900-1987). Diversos elementos trabalhados pelos espanhóis, em seu difícil objetivo de compreender e tentar explicar a Espanha, foram usados por Freyre para tentar compreender o Brasil. Em busca de um lugar para o Brasil na cultura hispânica, Freyre tentou romper as fronteiras que dividiam o continente latino-americano em português e em espanhol, reivindicando as duas tradições para o país. Bastos (2003) aponta diversas passagens da obra de Freyre em que o autor referencia os textos dos autores da geração espanhola de 1898, mostrando seu interesse pela discussão do universo hispânico.

7 Esse texto está enfeixado no livro En torno al casticismo, cuja edição utilizada aqui é a de 1968, mas a obra foi publicada em 1895. 
8 Nas Obras completas, esse texto está intitulado como "Rumbos nuevos". Nesse prólogo, Rodó (1957) define o livro de Torres como uma das grandes obras que expressam o idealismo no continente e afirma a necessidade de ser conhecida por todos os jovens literatos como uma fonte de inspiração ao "necessário" idealismo.

9 Essa temática é mais bem discutida em meu artigo intitulado "A América Latina indivisível: a influência do positivismo no projeto intelectual de José Enrique Rodó", publicado na revista Sociologias, Porto Alegre, v. 17, n. 40, pp. 380-414, set.-dez. 2015.

10 De acordo com Garzón (1990), em algumas passagens da obra Ariel (1900), Rodó concretiza sua influência do conceito de seleção natural de Darwin: "O valor seletivo da beleza nos animais como necessidade de todo progresso (no caso, social), como fator real de seleção espiritual, proeminência dos mais aptos, conquistando a realização no seio das sociedades humanas até o mais cru triunfo do struggle for life" (Garzón, 1990:173).

11 Segundo Tönnies (1947), a comunidade é o antigo; a sociedade, o novo, como coisa e nome. Comunidade é a vida comum, duradoura e autêntica; sociedade é apenas uma vida comum, passageira e aparente. Por isso, a primeira deve ser como um organismo vivo, e a segunda como agregado e artefato mecânico.

12 Unamuno escreveu esse livro em Paris, quando estava emigrado e refugiado por causa da ditatura pretoriana e cesariana espanhola na década de 1920. Afirmou que o concebeu em condições de ânimo singulares, o que chamou de "febre espiritual". 


\section{REFERÊNCIAS BIBLIOGRÁFICAS}

ABELLÁN, José Luis. (1964), “Aportaciones de Unamuno y Ortega para una Filosofía Española". Cuadernos de la Cátedra Miguel de Unamuno, v. 14, n. 14-15. Disponível em: <http://revistas.usal.es/index.php/0210-749X/article/view/9702>. Acesso em: 11 nov. 2015.

AGUINAGA, Carlos Blanco. (1984), Juventud de 98. Madrid: Santillana; Taurus.

ALAS, Leopoldo. (1961), “Estudio Crítico a Ariel”. In: J. E. Rodó. Ariel. México: EspasaCalpe Mexicana. pp. 11-21.

ALBERICH, José. (1959), “Sobre el positivismo de Unamuno”. Cuadernos de la Cátedra Miguel de Unaтипо, v. 9, n. 9. Disponível em: <http://revistas.usal.es/index.php/0210-749X/ article/view/9666/10032>. Acesso em: 11 nov. 2015.

ARDAO, Arturo. (1968), Espiritualismo y positivismo en el Uruguay. Montevideo: Departamento de Publicaciones de la Universidad de la Republica.

. (1980), Génesis de la idea y el nombre América Latina. Caracas: Centro de Estudios Latinoamericanos Rómulo Gallegos.

AZAM, Gilberto. (1989), El modernismo desde dentro. Barcelona: Anthropos.

AZÚA, Carlos Real de. (2001), Medio siglo de Ariel: su significación y transcendencia literario-filosófica. Montevideo: Academia Nacional de Letras.

BASTOS, Élide Rugai. (2003), Gilberto Freyre e o pensamento hispânico: entre Dom Quixote e Alonso El Bueno. Bauru, SP: Edusc.

BENÍTEZ, Hernán. (1949), El drama religioso de Unamuno. Buenos Aires: Instituto de Publicaciones.

BERMAN, Marshall. (1986), Tudo que é sólido desmancha no ar: a aventura da modernidade. São Paulo: Companhia das Letras.

BOLLO, Sarah. (1976), El modernismo en el Uruguay: ensayo estilístico. Montevideo: División Publicaciones y Ediciones Universidad de la Republica.

BORREGO, Francisco Javier. (2008), “Minerva y el Águila de Patmos: tradición clásica y referentes simbólicos en la obra poética de Miguel de Unamuno". Cuadernos de la Cátedra Miguel de Unamuno, vol. 45, n. 45. Disponível em: <http://revistas.usal.es/index. php/0210-749X/article/view/1261>. Acesso em: 2 nov. 2015.

CASANOVA, Juan F. G. (1993), “Del racionalismo armónico al pragmático: clave hermenéutica del poder real del institucionismo krausista". Revista del Centro de Estudios Constitucionales, v. 19, n. 14, pp. 99-126.

CHAVES, Julio Cesar. (1964), Unamuno y América. Madrid: Ediciones Cultura Hispánica.

COMTE, Auguste. (1978), Auguste Comte. Seleção de textos de José Arthur Giannotti. Trad. de José Arthur Giannotti e Miguel Lemos. São Paulo: Abril Cultural. (Coleção Os Pensadores).

CORTAZZO, Uruguay. (1986), “José Enrique Rodó y la elaboración de la tradición literaria". Revista de la Biblioteca Nacional, v. 1, n. 24, pp. 19-43. 
CÚNEO, Dardo. (1997), Sarmiento y Unamuno. Salamanca: Universidad de Salamanca.

DÍAS-QUIÑONES, Arcádio. (1998), "1898: Hispanismo y Guerra". In: BERNECKER, Walther L. (coord.). 1898: Su Significado para Centroamérica y el Caribe. Vervuet Verlag: Universität Erlangen-Nüremberg. pp. 17-35.

DURKHEIM, Émile. (1971), Moral education. New York: The Free Press.

GARZÓN, Fernando. (1990), Un Siglo de darwinismo: un ensayo sobre la historia de pensamiento biológico en el Uruguay. Montevideo: Facultad de Medicina.

GÓMEZ-MARTíNEZ, José Luis. (1981), Teoría del Ensayo. Salamanca: Universidad de Salamanca.

LEÓN, Manuel María U. (2001), “Unamuno en 1898: el reinado social de Jesús (en torno a un manuscrito inédito)". Cuadernos de la Cátedra Miguel de Unamuno, v. 36, n. 45. Disponível em: <http://revistas.usal.es/index.php/0210-749X/article/view/1474/1540>. Acesso em: 20 nov. 2015.

LITVAK, Lily. (1990), España 1900: modernismo, anarquismo y fin de siglo. Barcelona: Anthropos.

LÓPEZ, Julio. (1984), Unamuno. Madrid: Júcar. (Colección los Poetas).

LÖWY, Michael; SAYRE, Robert. (1993), Romantismo e politica. São Paulo: Paz e Terra.

MAÍZ, Claudio. (2009), Constelaciones unamunianas: enlaces entre España y América (18981920). Salamanca: Universidad Salamanca.

. (2010), "Unamuno entre nosotros: visiones cruzadas de la modernidad". Cuadernos del Pensamiento Latinoamericano, v. 1, n. 17, pp. 73-96.

MARRERO, Vicente. (1960), El Cristo de Unamuno. Madrid: Rialp.

MARTíNEZ, José María. (2009), “Modernismo literario y modernismo religioso: encuentros y desencuentros en Rubén Darío". Cuadernos del CILHA, vol. 10, n. 11, pp. 100-118.

MONEGAL, Emir Rodríguez. (1957), “Prefacio”. In: J. E. Rodó. Obras Completas. Madrid: Aguilar.

MORALES, Alfonso García. (1992), Literatura y pensamiento hispánico de fin de siglo: clarín y rodó. Sevilla: Publicaciones de Sevilla.

MORALES, María Belén de Castro. (1990), José Enrique Rodó modernista: utopía y regeneración. Isla Canarias: Universidad de la Laguna.

(2008), "El Ensayo Hispanoamericano del Siglo XX. Un Panorama Posible". In: T. Barrera (ed.), Historia de la literatura hispanoamericana: Siglo XX. Madrid: Cátedra. pp. 805-850. t. III.

PHELAN, John Leddy. (1993), "El origen de la idea de Latinoamérica". In: L. Zeao (ed.), Fuentes de la Cultura Latinoamericana. México: Fondo de Cultura Económica. pp. 461475. t. I.

PIERUCCI, Antônio Flávio. (2003), O desencantamento do mundo: todos os passos do conceito de Max Weber. São Paulo: Editora 34. 


\section{Elisângela da Silva Santos}

. (2008), "De olho na modernidade religiosa". Tempo Social, v. 20, n. 2, pp. 9-16. Disponível em: <http://dx.doi.org/10.1590/S0103-20702008000200001>. Acesso em: 2 dez. 2015.

QUIJANO, Aníbal. (2005), “Dom Quixote e os Moinhos de Vento na América Latina”. Estudos Avançados, vol. 19, n. 55, pp. 9-31.

. (2007), Modernidad, identidad y utopía en América Latina. Lima: Sociedad y Política.

RAMA, Angel. (1985), Rubén Darío y el Modernismo. Caracas; Barcelona: Alfadi Ediciones; Colección Trópicos.

RAMOS, Julio. (2008). Desencontros da Modernidade na América Latina: Literatura e Política no Século 19. Belo Horizonte: Ed. UFMG.

RODÓ, José Enrique. (1935), Prefacio. In: C. A. Torres. Idola Fori. Bogotá: Minerva.

(1957), Obras Completas. Compilación, prólogos y notas de Emir Rodríguez Monegal. Madrid: Aguilar.

ROJAS MIX, Miguel. (1991), Los cien nombres de América. Barcelona: Lumen.

SALINAS, Pedro. (1970), Literatura Española, Siglo XX. Madrid: Alianza.

STIER, María L. Lukac de. (2009), “Panoráma histórico de la filosofía política latinoamericana". Limite - Revista de Filosofía y Psicología, v. 4, n. 19, pp. 53-74.

TÖNNIES, Ferdinand. (1947), Comunidad y sociedad. Buenos Aires: Losada.

UNAMUNO, Miguel. (1938), La Agonía del Cristianismo. Buenos Aires: Losada. . (1957), “Correspondencias". In: J. E. Rodó. Obras Completas. Compilación, prólogos y notas de Emir Rodríguez Monegal. Madrid: Aguilar. Calpe.

(1968a), Algunas consideraciones sobre la literatura hispanoamericana. Madrid: Espasa. (1968b), En torno al casticismo. Madrid: Espasa-Calpe. . (1998), Diario íntimo. Madrid: Alianza.

(2002), Americanidad. Caracas: Biblioteca Ayacucho.

VENEGAS, Juana Sánchez-Gey. (1998), José Enrique Rodó (1871-1917). Madrid: Ediciones del Orto.

ZALDUMBIDE, Gonzalo. (1951), Cuatro clásicos americanos: Rodó, Montalvo, Fray Gaspar de Villarroel, P. J. B. Aguirre. Madrid: Ediciones Cultura Hispánica. 


\section{RESUMO \\ Dilemas da Transição em Miguel de Unamuno e José Enrique Rodó}

Neste artigo, o objetivo é discutir como o pensador uruguaio José Enrique Rodó (1871-1917) e o pensador espanhol Miguel de Unamuno (1864-1936) compreenderam a chamada crise de fim de século na Hispano-América. O interesse em resgatar as reflexões de dois autores de diferentes contextos geográficos é justamente perceber complementaridades que permitam a aproximação de ambas as reflexões que apontam para uma direção consensual entre religião e ciência no fim do século XIX. Para eles, a ausência total de um poder espiritual poderia ocasionar uma desordem moral, intelectual e psíquica na sociedade, uma vez que a religião se erigiu anteriormente como o grande sustentáculo do mundo. Portanto, a missão intelectual de ambos foi tentar encontrar a exata medida entre o arcabouço científico e a sensibilidade em um contexto marcado pelo processo de modernização de suas sociedades.

Palavras-chave: Miguel de Unamuno; José Enrique Rodó; pensamento social hispano-americano; modernização, crise

\section{ABSTRACT \\ Transition Dilemmas in Miguel de Unamuno and José Enrique Rodó}

The goal of this article is to discuss how the Uruguayan thinker José Enrique Rodó (1871-1917) and the Spanish thinker Miguel de Unamuno (1864-1936) understood the so-called end-of-century crisis in Spanish America. The interest in approaching the reflections of two authors from different geographic contexts is precisely to perceive complementarities in these reflections that point to a consensual direction with regards to religion and science in the late nineteenth century. For them, the total absence of spiritual power could bring about a moral, intellectual and psychic disorder in society, since religion was previously established as the main pillar of the world. Therefore, the intellectual mission of both was to try to find the exact balance between scientific framework and sensitivity in a context marked by the process of society's modernization.

Keywords: Miguel de Unamuno; José Enrique Rodó; Hispanic-American social thought; modernization; crisis 


\section{RÉSUMÉ \\ Dilemmes de Transition chez Miguel de Unamuno et José Enrique Rodó}

Dans cet article, l'objectif est d'analyser la manière dont le penseur uruguayen José Enrique Rodó (1871-1917) et le penseur espagnol Miguel de Unamuno (1864-1936) ont compris la soi-disant crise de la fin du siècle dans l'Amérique espagnole. L'intérêt de sauver les réflexions des deux auteurs de contextes géographiques différents veut précisément de percevoir des complémentarités permettant l'approximation des réflexions qui indiquent une direction consensuelle entre religion et science à la fin du XIXe siècle. Pour eux, l'absence totale de pouvoir spirituel pourrait entraîner un désordre moral, intellectuel et psychique dans la société, puisque la religion était auparavant considérée comme le grand soutien du monde. Par conséquent, leur mission intellectuelle était d'essayer à trouver la mesure exacte entre le cadre scientifique et la sensibilité dans un contexte marqué par le processus de modernisation de leurs sociétés.

MOTS-CLÉS: Miguel de Unamuno; José Enrique Rodó; Pensée Sociale Hispano-Américaine; modernisation, crise

\section{RESUMEN}

Dilemas de la Transición en Miguel de Unamuno y José Enrique Rodó

En este artículo, el objetivo es discutir cómo el pensador uruguayo José Enrique Rodó (1871-1917) y el pensador español Miguel de Unamuno (1864-1936) comprendieron la llamada crisis de fin de siglo en Hispanoamérica. El interés en rescatar las reflexiones de dos autores de diferentes contextos geográficos es, justamente, percibir complementariedades que permitan la aproximación de ambas reflexiones que apuntan a una dirección consensual entre religión y ciencia en el fin del siglo XIX. Para ellos, la ausencia total de un poder espiritual podría ocasionar un desorden moral, intelectual y psíquico en la sociedad, ya que la religión se erigió anteriormente como el grande sustentáculo del mundo. Por lo tanto, la misión intelectual de ambos fue intentar encontrar la medida exacta entre el marco científico y la sensibilidad en un contexto marcado por el proceso de modernización de sus sociedades.

Palabras clave: Miguel de Unamuno; José Enrique Rodó; pensamiento social hispanoamericano; modernización, crisis. 